\title{
Multivariate analysis of activated sludge community in full-scale wastewater treatment plants
}

\author{
Mateusz Sobczyk $^{1}$ (D) $\cdot$ Agnieszka Pajdak-Stós ${ }^{1} \cdot$ Edyta Fiałkowska ${ }^{1} \cdot$ Łukasz Sobczyk $^{1} \cdot$ Janusz Fyda $^{1}$
}

Received: 28 April 2020 / Accepted: 30 August 2020 / Published online: 12 September 2020

(C) The Author(s) 2020

\begin{abstract}
We investigated changes in protozoa and metazoa community in relation to process parameters in activated sludge from four wastewater treatment plants (WWTPs) throughout the period of 1 year. Principal component analysis (PCA) showed that activated sludge from investigated treatment plants had different dominating species representatives and community composition mainly depends on individual features of the treatment plants. Redundancy analysis (RDA) showed that the temperature in bioreactors was the most relevant factor explaining changes in the microorganism community, whereas reduction rate of chemical oxygen demand (COD), biological oxygen demand $\left(\mathrm{BOD}_{5}\right)$, suspended solids ( $\left.\mathrm{SS}\right)$, and total nitrogen (TN) did not sufficiently explain the variation in protozoa and metazoan community composition. The results indicate that in stable working WWTP it is difficult to find a pronounced link between activated sludge species composition, process parameters, and plant configuration. Applied multivariate analysis can be a valuable tool for the exploration of the relations between community composition and WWTP process parameters.
\end{abstract}

Keywords Activated sludge $\cdot$ Protozoa $\cdot$ Metazoa $\cdot$ Process parameters $\cdot$ PCA $\cdot$ RDA

\section{Introduction}

Curds and Cockburn (1970) were probably the first researchers who used the protozoa community as bioindicators of effluent quality of activated sludge system plants. Later, many attempts were made to relate the physicalchemical parameters of effluent or activated sludge with the present species of ciliates and other protozoa (Morishita 1976; Madoni and Ghetti 1981; Al-Shahwani and Horan 1991; Esteban et al. 1991; Salvadó et al. 1995; Perez-Uz et al. 2010; Hu et al. 2013a). The general conclusion from these researches indicates that each wastewater treatment plant

Responsible Editor: Diane Purchase

Electronic supplementary material The online version of this article (https://doi.org/10.1007/s11356-020-10684-5) contains supplementary material, which is available to authorized users.

Mateusz Sobczyk

mateusz.pawel.sobczyk@gmail.com

1 Institute of Environmental Sciences, Jagiellonian University, Gronostajowa 7, 30-387 Krakow, Poland
(WWTP) develops its own distinctive protozoan community which depends on the specific features of the plant itself (Seviour and Nielsen 2010) and no general and clear pattern exists. Attempt to explain this phenomenon was described by Salvadó et al. (1995), but statistical analyses used to relate physical-chemical parameters and protozoa showed that relation between various physical-chemical parameters and a particular species does not follow a linear model.

Long-term monitoring of the protozoa and metazoa community inhabiting activated sludge has already been conducted by scientists in several countries around the world: in Spain by Salvadó and Gracia (1993) and Martin-Cereceda et al. (1996), in Germany by Ettl (2001), in Austria by Foissner and Berger (1996), and in China by Zhou et al. (2006, 2008), Liu et al. (2008), and Hu et al. (2013a,b). However, results from most studies cannot be directly extrapolated to modern WWTPs designed for biological nutrient removal, and thus, new researches concerning bio-indicators are required (Perez-Uz et al. 2010; Dubber and Gray 2011). Recently Hu et al. (2013a,b), Zornoza (2017) observed and analyzed protozoa and metazoa community in a new types of WWTPs. Their study shows that some protozoa and metazoa representatives were related with the activated sludge system performance, particularly with effective nitrification process. 
The results from four full-scale WWTPs presented in this study fit very well to the current demand of biological analysis of activated sludge and are intended to draw attention to the deficiencies of the used methods. Throughout 1 year, the changes in protozoa and metazoa community composition in relation to changes in operational or environmental parameters were studied. Using of protozoa and metazoa as bioindicators of biological oxygen demand $\left(\mathrm{BOD}_{5}\right)$, chemical oxygen demand (COD), and of the effectiveness of the suspended solids (SS) and nitrogen (TN) removal process was evaluated.

\section{Materials and methods}

Samples were collected from four treatment plants operating in the Małopolska voivodship, southern Poland (Table 1). For the analysis 81 samples of activated sludge were taken from the WWTP aeration tanks.

\section{Influent, effluent quality and process parameters}

All investigated objects are municipal WWTPs. Plants SK, $\mathrm{NP}$, and $\mathrm{CH}$ additionally purify the variable volume of industrial sewage inflow. In all WWTPs phosphorous was reduced mainly by chemical precipitation (e.g., PIX dosing) so its values are not included in the data analysis.

Chemical analyses of influent and effluent parameters: SS, $\mathrm{COD}, \mathrm{BOD}_{5}, \mathrm{TN}$, and TP, were carried out by $\mathrm{SK}, \mathrm{CH}$, and SI WWTP laboratories or, as in the case of NP plant by the accredited laboratory of Municipal Water and Sewage Company in Kraków. The plants' operators provided information about operating parameters such as mixed liquor suspended solids (MLSS), hydraulic retention time (HRT), sludge load $(\mathrm{F} / \mathrm{M})$, temperature $(\mathrm{T})$, and the sludge volume index (SVI) of the mixed liquor. Sludge age was not calculated by operators in the investigated plants.

\section{Microscopic observation}

Microscopic analysis was conducted using the Nikon Eclipse 80i and Olympus IX 71 microscopes with $\times 200$ and $\times 400$ magnification. The density of protozoa and metazoa community was determined based on analysis of two or three $25 \mu \mathrm{l}$ drops taken from a well-mixed activated sludge sample, immediately after delivery to the laboratory. Small flagellates were counted along the diagonal in the Fuchs-Rosenthal chamber. The microbial density was averaged and recalculated for $1 \mathrm{ml}$ volume of activated sludge. Ciliate species determination was done based on Foissner et al. (1991, 1992, 1994, 1995, 1996) identification keys.

For data analysis protozoa and metazoa species were assigned to crawling, attached, swimming and predatory ciliates, naked and testate amoebas, metazoa, and flagellates. Rotifers, tardigrades, nematodes, and gastrotrichs were included into metazoa group. Flagellates consisted of two groups highlighted by Salvadó (1994), one group consisted of heterotrophic flagellates smaller than $20 \mu \mathrm{m}$, and the second of flagellates bigger than $20 \mu \mathrm{m}$.

\section{Statistics}

Principle component analysis (PCA) and redundancy analysis (RDA) were carried out on log-transformed densities of investigated protozoa and metazoa individuals. Response data were centered and standardized by species. PCA scores obtained for the first and second axes were used as the response variable in analysis of variance (ANOVA) and to check differences in species composition and process parameters between investigated treatment plants. The Tukey test was used as post hoc test. All statistical analyses were carried out in Canoco 5 (Ter Braak and Šmilauer 2012) and Statistica 13 (TIBCO Software Inc. 2017).

\section{Results}

\section{Process parameters}

The investigated WWTPs differed in process values (Table 2) and parameters (Table 3). The most pronounced differences between WWTPs were observed in TN and TP reduction rate.

PCA analysis (Fig. 1) showed that due to the analyzed process parameters, monitored WWTPs formed three separated groups along first PCA axis: SK WWTP, NP WWTP, and
Table 1 Main features of investigated WWTPs

\begin{tabular}{lllllll}
\hline $\begin{array}{l}\text { WWTP } \\
\text { code }\end{array}$ & Technology & $\begin{array}{l}\text { Real size } \\
\text { (people } \\
\text { equivalent) }\end{array}$ & $\begin{array}{l}\text { Mean sewage } \\
\text { flow }\left(\mathrm{m}^{3} / \text { day) }\right.\end{array}$ & $\begin{array}{l}\text { Working } \\
\text { biological tank } \\
\text { volume }\left(\mathrm{m}^{3}\right)\end{array}$ & $\begin{array}{l}\text { Industrial } \\
\text { waste }(\%)\end{array}$ & $\begin{array}{l}\mathrm{N} \text { and P } \\
\text { elimination }\end{array}$ \\
\hline SK & A2/O & 100,569 & 6387 & $6196+3698$ & 30 & Yes \\
NP & A2/O & 82,047 & 5269 & $4998 * 2$ & $35-40$ & Yes \\
CH & MLE & 73,915 & 15,142 & $2849 * 2$ & $15-20$ & Yes \\
SI & A2/O & 7462 & 923 & 1940 & 0 & No \\
\hline
\end{tabular}

A2/O anaerobic/anoxic/oxic, $M L E$ modified Ludzack-Ettinger process 
Table 2 Values of process parameters in investigated WWTPs. Mean \pm standard deviation $(\mathrm{SD})$

\begin{tabular}{llllll}
\hline WWTP & MLSS $(\mathrm{g} / \mathrm{L})$ & $\mathrm{T}\left({ }^{\circ} \mathrm{C}\right)$ & HRT (days) & F/M (gBOD $/$ gMLSS/day) & SVI \\
\hline SK & $4.73 \pm 0.64$ & $17.7 \pm 2.3$ & $1.18 \pm 0.18$ & $0.09 \pm 0.04$ & $139.3 \pm 27.6$ \\
NP & $4.19 \pm 0.54$ & $18.4 \pm 3.6$ & $1.65 \pm 0.15$ & $0.14 \pm 0.08$ & $128.6 \pm 36.1$ \\
CH & $5.00 \pm 0.77$ & $12.5 \pm 3.9$ & $0.37 \pm 0.09$ & $0.07 \pm 0.05$ & $170.6 \pm 30.4$ \\
SI & $4.20 \pm 0.87$ & $12.8 \pm 4.7$ & $4.37 \pm 0.81$ & $0.01 \pm 0.006$ & $194.9 \pm 34.2$ \\
\hline
\end{tabular}

CH WWTP with SI WWTP and three separated groups along second PCA axis: SK with NP WWTP, CH WWTP, and SI WWTP. ANOVA analysis on first and second axis PCA scores showed that investigated WWTPs differ in process parameters (Axis 1: $F_{(3,77)}=30.17, p<0.001$ and Axis 2: $F_{(3,77)}$ $=72.82, p<0.001)$. PCA diagram (Fig. 1) explained $79.51 \%$ of the variance in process parameters values.

\section{Functional group composition}

During the study 34 ciliated protozoa assigned to functional groups were found. The list of protozoa and metazoa observed is included in supplementary materials (Table S1). In each of the investigated WWTPs, high fluctuations in time among protozoa and metazoa density and species composition were noticed (Fig. 2a, b, c, d). The fluctuations in protozoa and metazoa density were higher in bigger WWTPs (SK and $\mathrm{NP}$ ) than in smaller ones (CH and SI). The most stable functional groups (with the lowest coefficient of variation $\mathrm{CV}$ value) were different in each WWTP during the monitoring period. In SK plant it was crawling ciliates $(\mathrm{CV}=0.49)$, in NP predatory ciliates $(\mathrm{CV}=0.53)$, in $\mathrm{CH}$ flagellates $(\mathrm{CV}=0.57)$, and in SI attached ciliates $(\mathrm{CV}=0.55)$. The higher density of flagellates and testate amoebae were observed in bigger WWTPs (SK and NP) then in CH and SI. In SK treatment plant during winter months in 2017 high peak of testate amoebae, represented mainly by Cochlipodium sp., was observed
(Fig. 2a). Crawling and attached ciliates were the most numerous functional groups in all WWTPs. The least numerous of all functional groups in all treatment plants were swimming ciliates.

\section{Functional group composition in investigated WWTPs}

The PCA biplot (Fig. 3) showed that none of the monitored WWTPs significantly differed from others in the composition of functional groups. Only one sample from SK and one sample from SI differed strongly from the remaining samples in functional group composition. Non-parametric KruskalWallis test on first and second axis PCA scores showed that investigated WWTPs did not differ in functional group composition. ANOVA analysis was not performed because the assumption of homogeneity of variance and normal distribution of residuals were not met.

\section{Species composition in investigated WWTP}

ANOVA analysis performed on first and second PCA axis scores showed that investigated WWTPs differ in assemblage of protozoa and metazoa species (Axis 1: $F_{(3,77)}=26.37, p<$ 0.001 and Axis 2: $\left.F_{(3,77)}=19.05, p<0.001\right)$ (Fig. 4). The significant differences in protozoa and metazoa communities observed between WWTPs are presented in Fig. 5 a and b. Based on the results of this analysis specific dominated
Table 3 Chemical parameters of the influent, effluent, and reduction rate in investigated WWTPs (mean \pm SD)

\begin{tabular}{lllllll}
\hline WWTP & & SS & BOD $_{5}$ & COD & TN & TP \\
\hline SK & Influent (mg/l) & $889 \pm 487$ & $872 \pm 264$ & $1600 \pm 342$ & $133 \pm 33.8$ & $18.2 \pm 7.9$ \\
& Effluent (mg/l) & $7 \pm 3$ & $6 \pm 2$ & $59 \pm 14$ & $10.6 \pm 1.7$ & $0.7 \pm 0.9$ \\
& Reduction (\%) & $99.1 \pm 0.6$ & $99.3 \pm 0.3$ & $96.1 \pm 1.2$ & $91.4 \pm 2.7$ & $95.1 \pm 7.5$ \\
NP & Influent (mg/l) & $593 \pm 476$ & $934 \pm 489$ & $2151 \pm 1178$ & $101.6 \pm 33.8$ & $12.7 \pm 5.5$ \\
& Effluent (mg/l) & $10 \pm 7$ & $6 \pm 4$ & $41 \pm 13$ & $13.6 \pm 7.7$ & $0.8 \pm 2.1$ \\
& Reduction (\%) & $97.9 \pm 1.6$ & $99.3 \pm 0.4$ & $97.6 \pm 1.3$ & $85.7 \pm 7.5$ & $93.7 \pm 16.2$ \\
CH & Influent (mg/l) & $292 \pm 106$ & $293 \pm 119$ & $630 \pm 197$ & $49.2 \pm 11.1$ & $8.8 \pm 4.0$ \\
& Effluent (mg/l) & $10 \pm 10$ & $8 \pm 7$ & $24 \pm 9$ & $10.8 \pm 8.6$ & $0.8 \pm 0.5$ \\
& Reduction (\%) & $96.2 \pm 3.3$ & $97.2 \pm 2.5$ & $95.7 \pm 2.0$ & $77.2 \pm 17.7$ & $89.9 \pm 5.6$ \\
SI & Influent (mg/l) & $546 \pm 221$ & $492 \pm 204$ & $1001 \pm 372$ & $89.5 \pm 20.82$ & $10.9 \pm 2.6$ \\
& Effluent (mg/l) & $4 \pm 4$ & $5 \pm 4$ & $32 \pm 9$ & $16.9 \pm 2.9$ & $4.5 \pm 2.2$ \\
& Reduction (\%) & $99.1 \pm 0.7$ & $98.8 \pm 0.7$ & $96.5 \pm 1.4$ & $80.4 \pm 4.4$ & $54.2 \pm 28.4$ \\
\hline
\end{tabular}




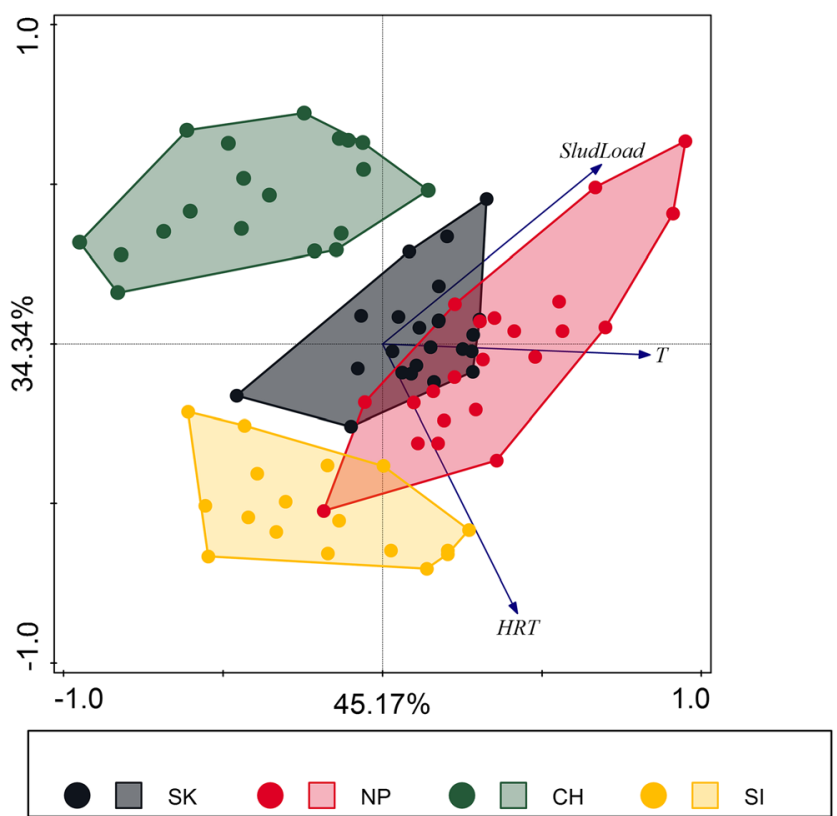

Fig. 1 PCA analysis of process parameters of all data received during the monitoring. Arrows represent process parameters. Dots represent WWTP: black-SK, red-NP, green- $\mathrm{CH}$, and yellow-SI. The first axis explained $45.17 \%$ and the second axis $34.34 \%$ of the variance in process parameters

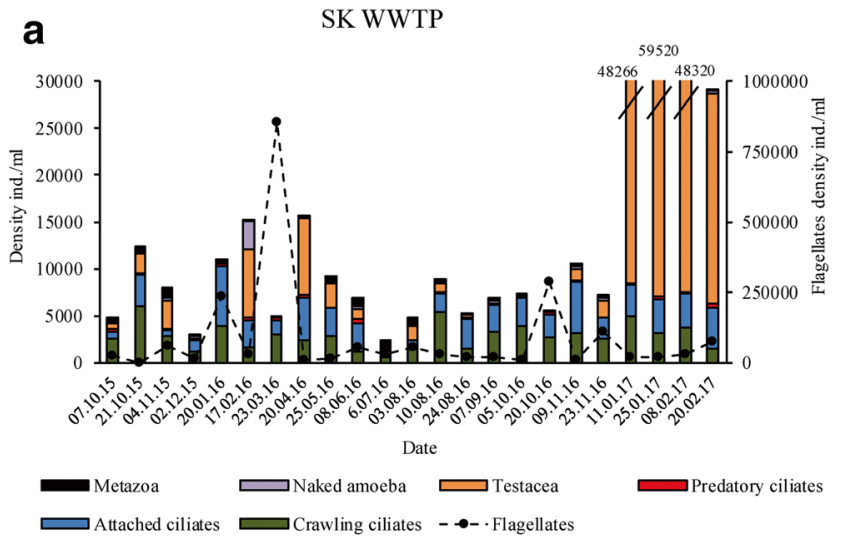

C

CHWWTP

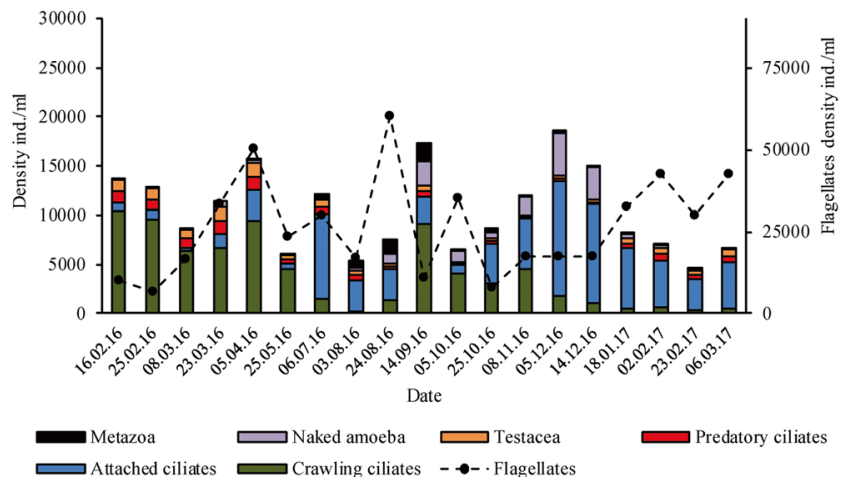

representatives of protozoa and metazoa for individual WWTP could be defined. During the monitoring period, based on the first PCA axis scores NP WWTP differs significantly from other WWTPs. In NP WWTP dominated Arcella sp., Peranema sp., Epistylis chrysemidis, and metazoa such as gastrotrichs, nematodes, and monogononta rotifers. SK WWTP had a similar community to $\mathrm{CH}$ WWTP, and SI WWTP had similar protozoa and metazoa assemblage to $\mathrm{CH}$ WWTP (Fig. 5a). Along the second PCA axis, WWTPs formed two groups: first SK with SI where the density of Microthorax pusillus, Metacystis sp., Thuricola sp., and tardigrades tend to be higher and second NP with $\mathrm{CH}$ where occurrence of Opercularia spp. were higher (Figs. 4 and 5b).

However, it should be considered that PCA diagram (Fig. 4) explained only $20.00 \%$ of the variance in protozoa and metazoa species composition.

\section{Functional groups composition explained by process and operational parameters}

On RDA triplot diagram (Fig. 6) the first ordination axis is correlated mainly with the activated sludge temperature. The abundance of total metazoa tends to be larger at higher

b

NP WWTP

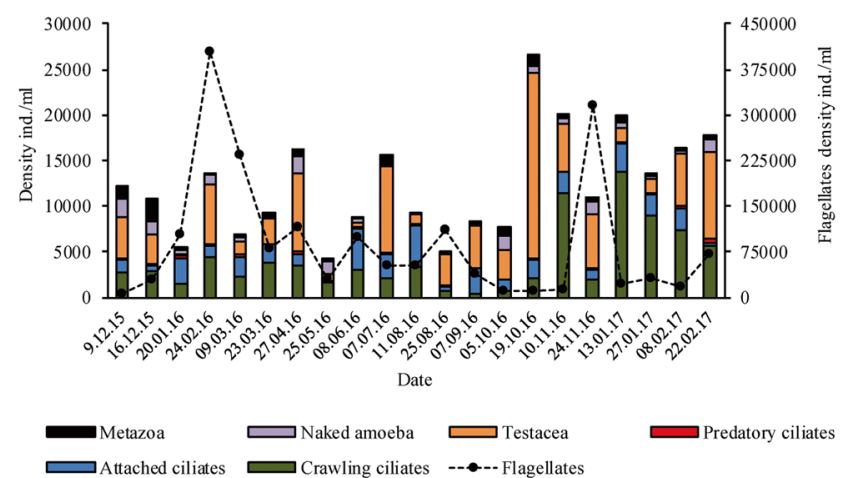

d

SI WWTP

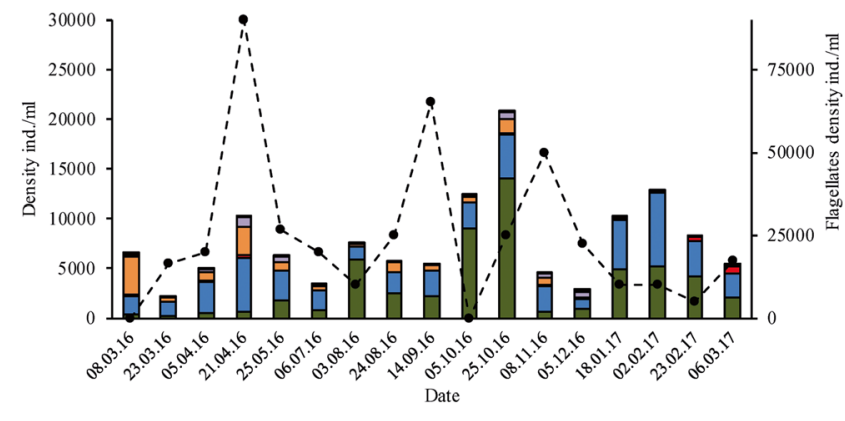

$\begin{array}{ll}\text { Metazoa } & \text { Naked amoeba } \rightleftharpoons \text { Testacea } \\ \text { Attached ciliates } & \text { Crawling ciliates } \\ \text { - }- \text { - Flagellates }\end{array}$

Fig. 2 Annual variations of the density of functional groups in SK WWTP (a), annual variations of the density of functional groups in NP WWTP (b), annual variations of the density of functional groups in CH WWTP (c), and annual variations of the density of functional groups in SI WWTP (d) 


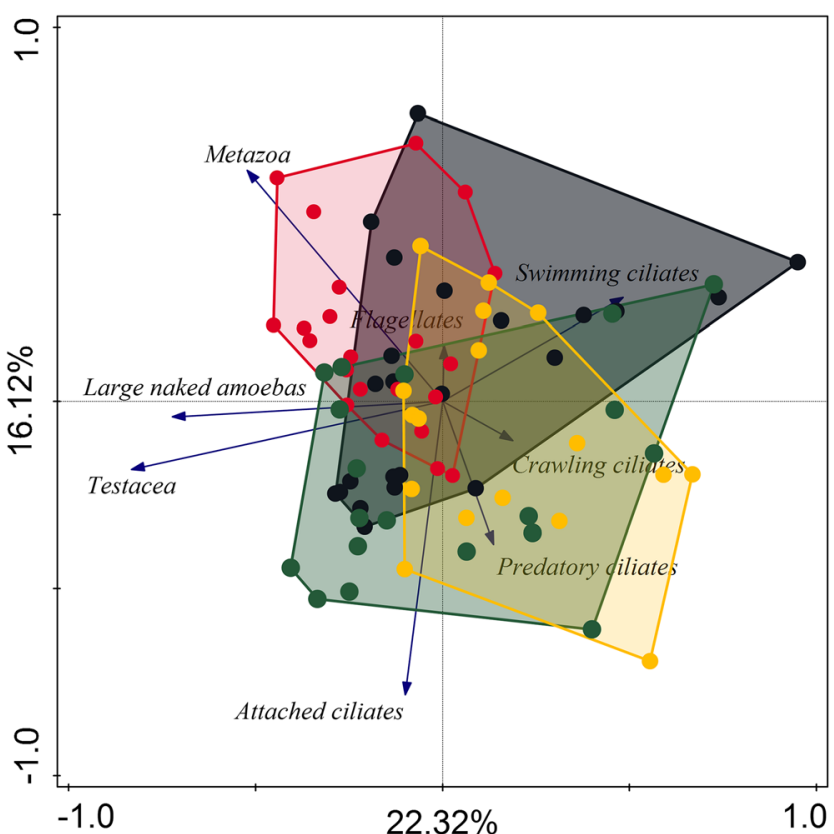

Fig. 3 PCA analysis of the functional group composition of all data received during the monitoring. Dots represent WWTP: black-SK, red-NP, green - $\mathrm{CH}$, and yellow-SI. The first axis explained $22.32 \%$ and the second axis $16.12 \%$ of the variance in activated sludge functional group community

temperatures, and simultaneously abundance of attached ciliates tends to be larger at a lower temperature. The second ordination axis was more correlated with HRT. The density

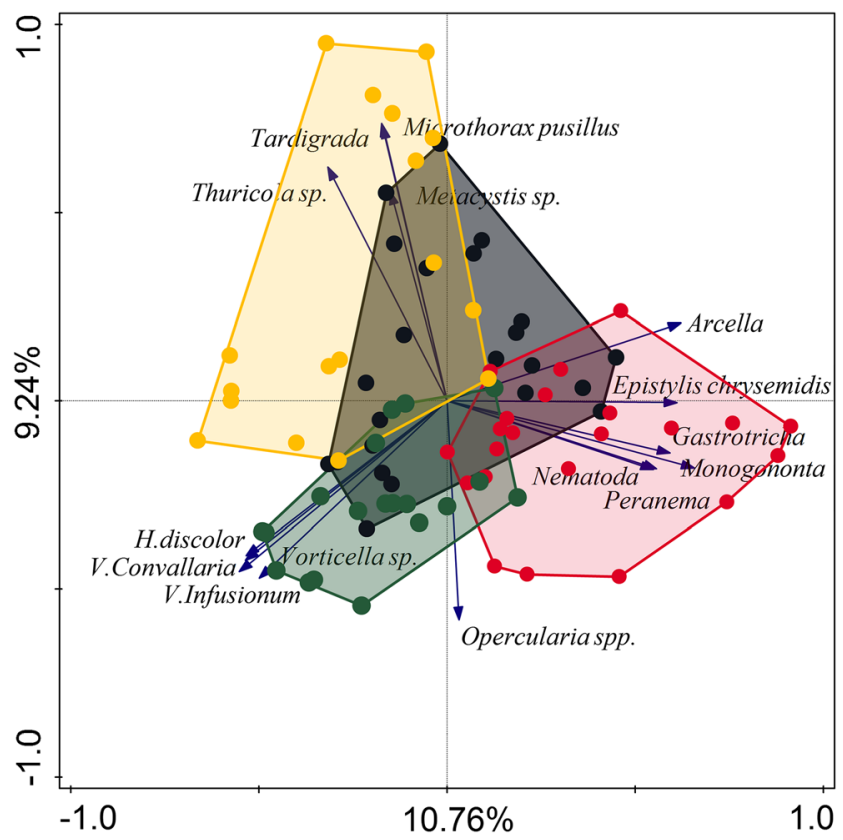

Fig. 4 PCA analysis of activated sludge biocenosis composition of all data received during the monitoring. Arrows represent 15 best fitted protozoa and metazoa representatives. Dots represent WWTP: black$\mathrm{SK}$, red-NP, green $-\mathrm{CH}$, and yellow-SI. The first axis explained $10.76 \%$ and the second axis $9.24 \%$ of the variance in protozoa and metazoa activated sludge community
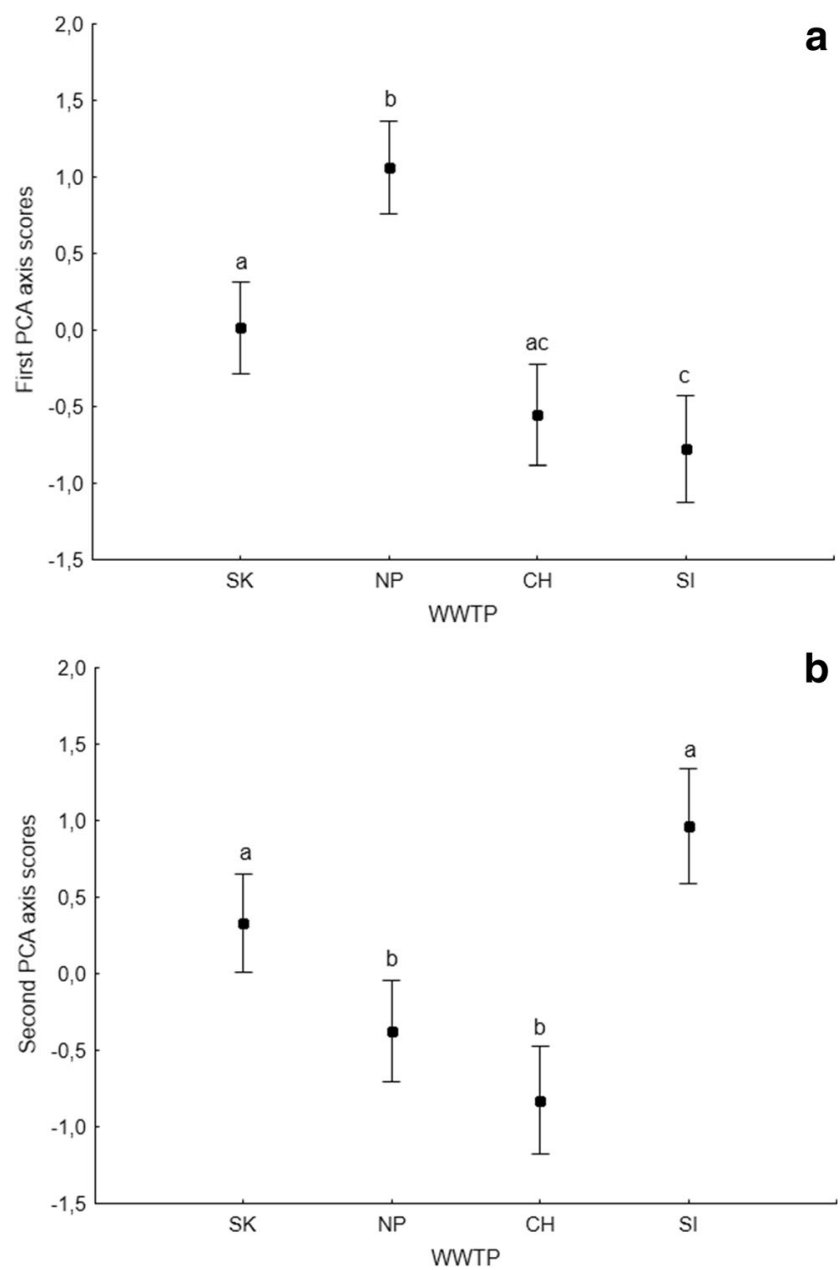

Fig. 5 Differences in protozoa and metazoa community between investigated WWTPs based on first (a) and second PCA axis scores (b). Vertical bars denote $95 \%$ confidence intervals.

of predatory ciliates tends to be lower at higher HRT values. The density of testate amoebas, large naked amoebas, and flagellates tends to be higher at higher sludge load value. The effect of temperature, sludge load, and HRT on functional groups community was significant $(p=0.002)$, and both ordination axes in Fig. 6 explained 12.66\% of the variance in functional groups composition.

As was mentioned earlier, WWTPs distinctly differ in values of operational parameters (Fig. 1; Tables 1 and 2) so it should be taken into account that the effects of process parameters upon species were also correlated with single treatment plant traits.

\section{Protozoa and metazoa community composition explained by process and operational parameters}

On RDA triplot diagram (Fig. 7) the first ordination axis is correlated mainly with the activated sludge temperature. The abundance of testate amoeba-Arcella sp. and ciliates 


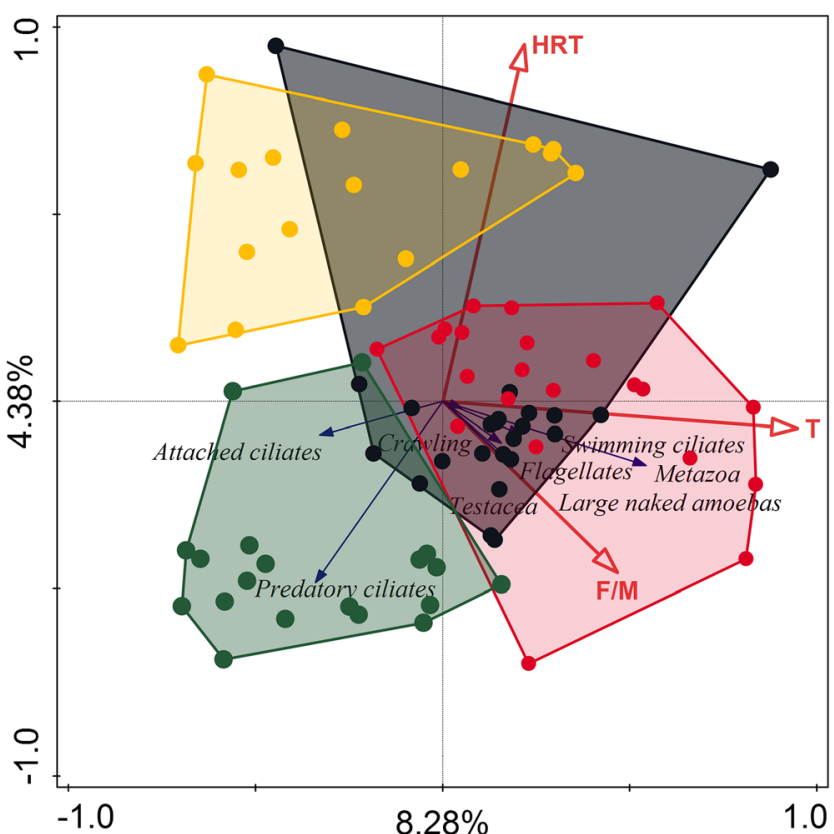

Fig. 6 Triplot diagram from RDA summarizing the effects of process parameters descriptors upon functional/ecological groups in activated sludge. Dots represent WWTP: black-SK, red-NP, green- $\mathrm{CH}$, and yellow-SI. About $8.28 \%$ (first axis) and $4.38 \%$ (second axis) of the variance in functional group composition were explained by process parameters descriptors

A. cicada, and Chilodonella sp.- - tends to be higher at higher temperatures. On the other hand, the probability of Vorticella sp., $V$. convallaria, and $H$. discolor occurrence was higher at lower temperatures. The second ordination axis was more correlated with HRT. The density of the ciliate M. pusillus was higher at higher HRT values. In turn, the probability of the occurrence of attached ciliates Opercularia spp. was higher at lower HRT values. The effects of temperature, sludge load, and HRT on protozoa and metazoa community were significant $(p=0.002)$, and both ordination axes in Fig. 7 explained $11.48 \%$ of the variance in their community composition.

The SI WWTP microorganism community forms a separate cluster (yellow dots in Fig. 7) compared with other treatment plants in relation to investigated process parameters. As was mentioned earlier, WWTPs distinctly differ in values of operational parameters (Fig. 1; Tables 1 and 2) so it should be taken into account that the effects of process parameters descriptors upon protozoa and metazoa communities were also correlated with single treatment plant traits.

\section{Protozoa and metazoa community explained by SVI}

On RDA biplot diagram (Fig. 8) the abundance of flagellates Peranema sp. and both groups of rotifers: Monogononta and Bdelloidea, corresponded with the lower value of SVI.

\section{Protozoa and metazoa community composition explained by reduction rate of some pollution measures}

In RDA analysis predictors, $\mathrm{SS}, \mathrm{BOD}_{5}, \mathrm{COD}$, and $\mathrm{TN}$ had insignificant $(p=0.086$ ) effect on functional group composition (data not shown). On RDA biplot diagram (Fig. 9) the first ordination axis is weakly correlated with suspended solid reduction rate. The density of ciliates: Thuricola sp., Metacystis sp., Plagiocampa rouxi, and tardigrades, tend to be higher at higher suspended solid reduction rate. Testate Arcella sp. abundance was strongly correlated with $\mathrm{BOD}_{5}$ reduction rate, while predatory ciliates $H$. discolor was strongly negatively correlated with $\mathrm{BOD}_{5}$ and $\mathrm{TN}$ reduction rate. Suctoria and A. cicada tend to be more abundant at higher $\mathrm{BOD}_{5}$ and total nitrogen reduction rate. The second ordination axis is weakly correlated with COD and the total nitrogen reduction rate. The probability of the occurrence of Vorticella sp. is lower when the values of COD reduction rate are higher. The higher reduction rate of $\mathrm{BOD}_{5}$ and $\mathrm{TN}$ corresponded with higher abundance of Arcella sp. Reduction rates significantly correlate with protozoa and metazoa community ( $p=0.002$ ), and both ordination axes explained $7.77 \%$ of the variance in their community composition.

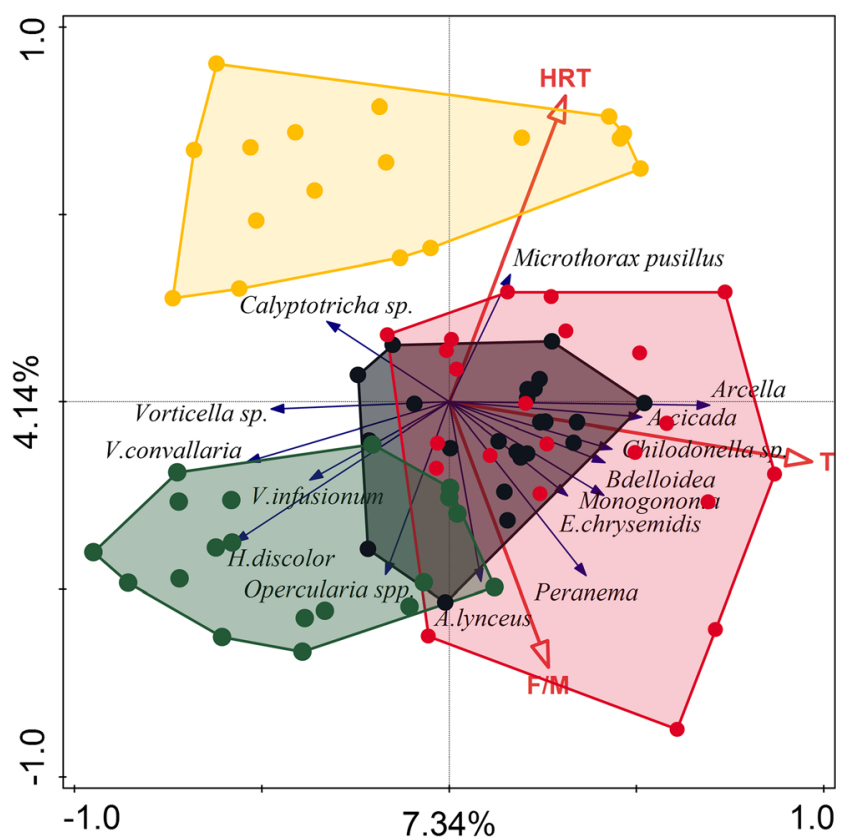

Fig. 7 Triplot diagram from RDA summarizing the effects of process parameters descriptors upon protozoa and metazoa communities in activated sludge. Dots represent WWTP: black-SK, red-NP, green$\mathrm{CH}$, and yellow-SI, and 15 best fitted protozoa and metazoa representatives are shown. About $7.34 \%$ (first axis) and $4.14 \%$ (second axis) of the variance in microbial community composition were explained by process parameters descriptors. 


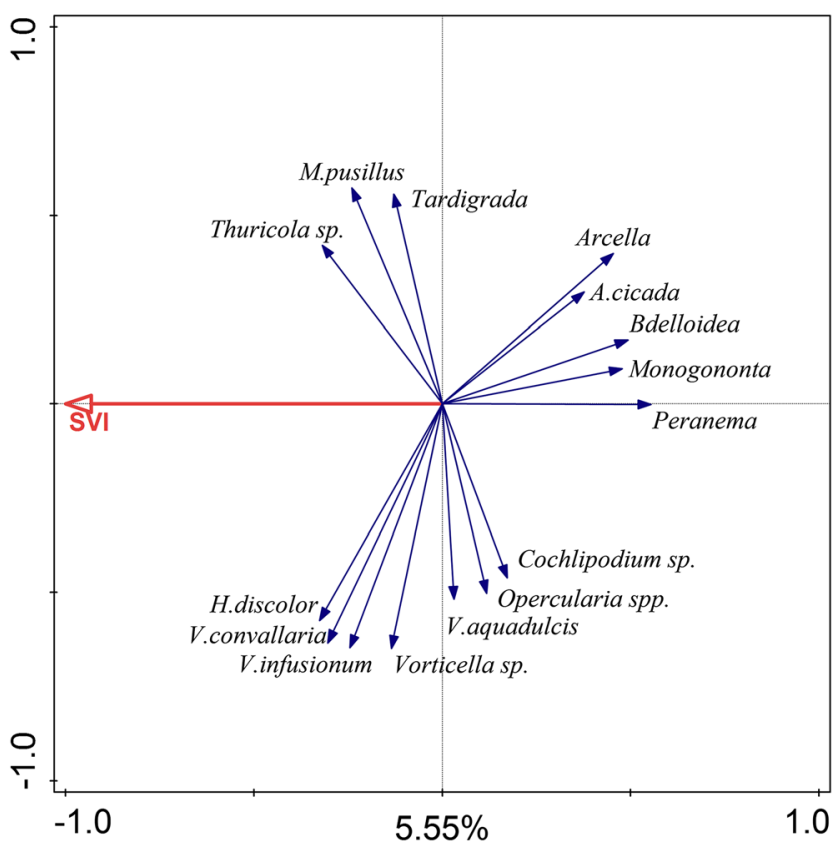

Fig. 8 Biplot diagram from RDA analysis showing the effects of SVI upon protozoa and metazoa communities in activated sludge. The effect of SVI on protozoa and metazoa community was significant $(p=0.002)$. About $5.55 \%$ (first axis) of the variance in microbial community were explained

\section{Discussion}

Our results, similarly to Zornoza's (2017) research, suggest that density and species composition of protozoa and metazoa in activated sludge depend on bioreactor configuration (volume and technology used). According to Zornoza, the temperature has more direct effect on variability in microbial communities than sludge age. On the other hand, the temperature is closely related to sludge age, because of common practice to increase the sludge age with the decrease of the nitrifying activity at the low temperatures in the bioreactors (Dymaczewski 2011).

In research conducted by Hu and co-workers (2013b) influent temperature and SVI showed the highest factorial loads in the first component axis in PCA exploring changes in protozoa and metazoa community. Results of our RDA analysis (Fig. 7) were similar, although instead of the temperature of influent, the temperature in a bioreactor of studied WWTPs was applied. Our study showed that the effect of temperature on protozoa and metazoa community was significant but the first ordination axis explained only $7.34 \%$ of the variance in community composition. Changes in SVI had a significant effect on protozoan and metazoan community but explained only $5.55 \%$ of the variance in species composition. It should be mentioned that occurrence and density of metazoa, especially rotifers, are correlated with temperature and SVI. Fiałkowska and Pajdak-Stós (2008) showed that rotifers Lecane inermis were able to consume and reduce the number of filamentous bacteria in activated sludge and are therefore able to reduce SVI value. These reductions strongly depend on temperature. With decreasing temperature, rotifer density decreases, and thus, rotifer pressure on filamentous bacteria weakens and as a consequence SVI values increases (Pajdak-Stós and Fiałkowska 2012). A similar and significant correlation between individual protozoa taxa and the temperature of influent, effluent, and activated sludge in aeration tanks was found by Ettl (2001). A strong temperature effect on the protozoa community structure could be explained by their correlation with the metabolic activity of ciliates (Laybourn and Finlay 1976). Likewise, Weisse et al. (2002) described an interaction between temperature and food concentration and their effect on the growth and production of planktonic protozoa. A recent study conducted by Wu et al. (2019) on 1200 activated sludge samples collected from 23 countries confirmed that temperature is a key factor influencing activated sludge bacterial community structure. Hai et al. (2014) showed that operational parameters: MLSS, SRT, HRT, and temperature, explained $19.9 \%$ of bacterial community variation. Fan et al. (2017) did not include the temperature as an operating factor but treated temperature as a separate factor and in their analysis temperature alone explained $9.20 \%$ of bacterial community variation. Likewise, Fredriksson et al. (2019) suggested that temperature and ethanol addition were the environmental parameters contributing the most to the temporal differences in bacterial community composition. As protozoa and metazoa are main bacterial feeders the changes in a bacterial community may directly affect protozoa and metazoan community. These results showed that factors independent of

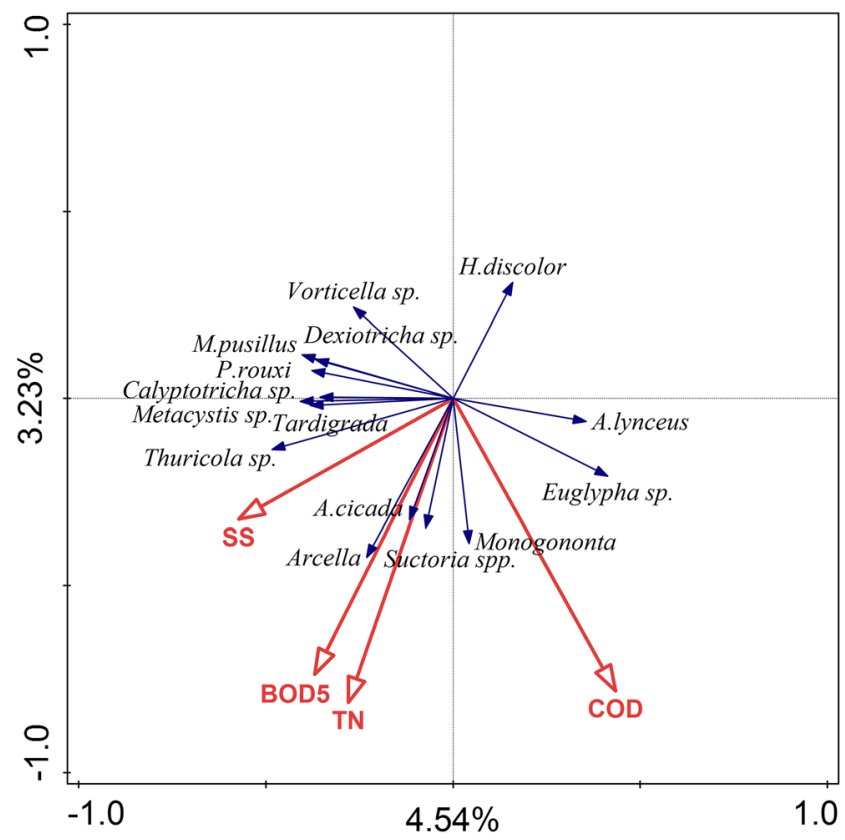

Fig. 9 Biplot diagram from RDA analysis summarizing the effects of the reduction rate of pollution descriptors upon protozoa and metazoa communities in activated sludge. Fifteen best fitted protozoa and metazoa representatives are shown. About $4.54 \%$ (first axis) and $3.23 \%$ (second axis) of the variance in microbial community composition were explained by the reduction rate of pollution measures 
plant operators have the strongest effect on protozoa community in activated sludge of WWTPs.

Fluctuations in species composition and dominance structure in ciliate community during 1-year study were described by Ettl (2001) and Chen et al.(2004). Similarly to our study, the abundance and density of the different species were very variable, but simultaneously, the performance of all plants was fairly stable during the year of sampling. Thus, the researchers also did not find any consistent bioindicator species of process performance in protozoa and metazoa community.

In Tables 4 and 5 we gathered the results from studies conducted in different parts of the world. A comparison of results obtained by different authors also did not show any consistent relationships between ciliated protozoa species and process parameters. Basing on these comparative results it is hard to find a general pattern describing a relation between specific protozoa

Table 4 Value of correlation coefficients between ciliated protozoa species and process parameters in activated sludge investigated by others authors

\begin{tabular}{|c|c|c|c|c|c|c|c|c|}
\hline Species & $\begin{array}{l}\text { Effluent } \\
\text { BOD }\end{array}$ & $\begin{array}{l}\text { Effluent } \\
\text { COD }\end{array}$ & $\begin{array}{l}\text { Effluent } \\
\text { SS }\end{array}$ & $\begin{array}{l}\text { BOD } \\
\text { removal }\end{array}$ & $\begin{array}{l}\text { COD } \\
\text { removal }\end{array}$ & SVI & Nitrification & Reference \\
\hline \multirow[t]{7}{*}{ Aspidisca cicada } & -0.233 & & -0.123 & & & 0.02 & & Zhou (2006) \\
\hline & & -0.087 & & -0.064 & 0.064 & & -0.452 & Dubber and Gray (2011) \\
\hline & $-0.34 * * *$ & $-0.467^{*}$ & $-0.462^{*}$ & & & & & $\begin{array}{l}\text { Drzewicki and Kulikowska } \\
\text { (2011) }\end{array}$ \\
\hline & -0.791 & & -0.82 & & & & & Salvadó (1995) \\
\hline & 0.05 & -0.2 & $0.71 * * *$ & & & -0.26 & & dos Santos (2014) \\
\hline & $-0.794 * *$ & $-0.833 * *$ & & & & & & Papadimitriou (2007) \\
\hline & -0.18 & & & & & 0.13 & & Lee (2004) \\
\hline Aspidisca lynceus & & -0.033 & & -0.282 & -0.167 & & -0.129 & Dubber and Gray (2011) \\
\hline \multirow[t]{4}{*}{ Acineria uncinata } & & $0.609 *$ & & -0.309 & -0.336 & & -0.345 & Dubber and Gray (2011) \\
\hline & -0.01 & & & & & 0.22 & & Lee (2004) \\
\hline & -0.925 & & -0.814 & & & & & Salvadó (1995) \\
\hline & $0.892 * * *$ & $0.852 * * *$ & $0.665 * * *$ & & & & & $\begin{array}{l}\text { Drzewicki and Kulikowska } \\
\text { (2011) }\end{array}$ \\
\hline \multirow{2}{*}{$\begin{array}{l}\text { Tritigmostoma } \\
\text { cucullulus }\end{array}$} & & -0.187 & & & 0.36 & & 0.556 & Dubber and Gray (2011) \\
\hline & -0.13 & & & & & 0.03 & & Lee (2004) \\
\hline \multirow[t]{6}{*}{ Opercularia spp. } & $0.358 *$ & & $0.269^{*}$ & & & -0.19 & & Zhou (2006) \\
\hline & 0.17 & & & & & -0.13 & & Lee (2004) \\
\hline & $0.336^{*}$ & -0.108 & & & & 0.11 & & Esteban (1991) \\
\hline & 0.21 & 0.03 & -0.08 & & & 0.06 & & dos Santos (2014) \\
\hline & $-0.658 * *$ & -0.692 & & & & & & Papadimitriou (2007) \\
\hline & & & & $-0.763 * * *$ & & & $-0.597 * * *$ & Madoni (2011) \\
\hline \multirow[t]{6}{*}{ Vorticella convallaria } & $-0.402 * * *$ & & $0.293^{*}$ & & & -0.103 & & Zhou (2006) \\
\hline & & & & $0.609 *$ & 0.591 & & 0.145 & Dubber and Gray (2011) \\
\hline & -0.938 & & -0.878 & & & & & Salvadó (1995) \\
\hline & $-0.614 * *$ & -0.551 & & & & & & Papadimitriou (2007) \\
\hline & 0.65 & & $0.857 * *$ & $0.621 *$ & & $-0.56^{*}$ & & Ntougias (2011) \\
\hline & 0.1 & & & & & -0.11 & & Lee (2004) \\
\hline \multirow[t]{6}{*}{ Vorticella microstoma } & -0.1 & & & & & $\begin{array}{l}- \\
0.26- \\
* *\end{array}$ & & Lee (2004) \\
\hline & & & & -0.679 & & & -0.504 & Madoni (2011) \\
\hline & -0.608 & & -0.572 & & & & & Salvadó (1995) \\
\hline & -0.13 & -0.06 & & & & & & Papadimitriou (2007) \\
\hline & 0.21 & -0.21 & $-0.37 *$ & & & -0.02 & & dos Santos (2014) \\
\hline & $-0.342 *$ & -0.054 & & & & $\begin{array}{l}- \\
0.61- \\
* *\end{array}$ & & Esteban (1991) \\
\hline Arcella sp. & $-0.806^{* *}$ & $-0.895 * *$ & $-0.508 * *$ & & & & & Papadimitriou (2007) \\
\hline
\end{tabular}

$* p<0.05, * * p<0.01, * * * p<0.001$ 
Table 5 Value of correlation coefficients between functional groups of protozoa and process parameters in activated sludge investigated by other authors

\begin{tabular}{|c|c|c|c|c|c|c|c|}
\hline Functional group & Effluent BOD & Effluent COD & Effluent SS & BOD removal & SVI & Nitrification & Reference \\
\hline \multirow[t]{6}{*}{ Attached ciliates } & & & & & $0.66^{*}$ & & $\mathrm{Hu}(2012)$ \\
\hline & & & & & $0.85^{*}$ & & $\mathrm{Hu}(2012)$ \\
\hline & -0.34 & & & & -0.03 & & Martin-Cereceda (1996) \\
\hline & $0.695 * *$ & & $0.891 * *$ & $0.603 * *$ & $-0.63 *$ & & Ntougias (2011) \\
\hline & -0.247 & & -0.2 & & 0.15 & & Zhou (2008) \\
\hline & & & & $0.432 * *$ & & -0.029 & Madoni (2011) \\
\hline \multirow[t]{6}{*}{ Crawling ciliates } & & & & $0.784 * * *$ & & $0.62 * * *$ & Madoni (2011) \\
\hline & $-0.394 * *$ & & $-0.283^{*}$ & & 0.03 & & Zhou (2008) \\
\hline & 0.08 & & & & 0.17 & & Martin-Cereceda (1996) \\
\hline & 0.17 & -0.17 & $0.77 * * *$ & & -0.22 & & dos Santos (2014) \\
\hline & & & & & -0.26 & & $\mathrm{Hu}(2012)$ \\
\hline & & & & & 0.32 & & $\mathrm{Hu}(2012)$ \\
\hline \multirow[t]{6}{*}{ Swimming ciliates } & & & & $-0.829 * * *$ & & $-0.549 * * *$ & Madoni (2011) \\
\hline & 0.078 & & 0.073 & & 0.27 & & Zhou (2008) \\
\hline & 0.52 & & & & 0.03 & & Martin-Cereceda (1996) \\
\hline & 0.01 & & -0.13 & & 0.36 & & dos Santos (2014) \\
\hline & & & & & 0.28 & & $\mathrm{Hu}(2012)$ \\
\hline & & & & & 0.35 & & $\mathrm{Hu}(2012)$ \\
\hline \multirow[t]{6}{*}{ Flagellates } & & & & $-0.798 * * *$ & & $-0.596^{* * *}$ & Madoni (2011) \\
\hline & 0.024 & & 0.213 & & $0.47 * * *$ & & Zhou (2008) \\
\hline & $0.43 *$ & -0.2 & 0.21 & & 0.17 & & dos Santos (2014) \\
\hline & & & & & 0.48 & & Hu (2012) \\
\hline & & & & & 0.05 & & $\mathrm{Hu}(2012)$ \\
\hline & $0.67 * * *$ & $0.635^{* * *}$ & $0.62 * * *$ & & & & Drzewicki and Kulikowska (2011) \\
\hline \multirow[t]{6}{*}{ Testate amoebae } & & & & $0.76^{* * *}$ & & $0.912 * * *$ & Madoni (2011) \\
\hline & $-0.367 * * *$ & & -0.281 & & $-0.52 * * *$ & & Zhou (2008) \\
\hline & $0.22 *$ & & & & 0.09 & & Lee (2004) \\
\hline & 0.03 & -0.14 & $0.53 * *$ & & -0.29 & & dos Santos (2014) \\
\hline & & & & & 0.10 & & $\mathrm{Hu}(2012)$ \\
\hline & & & & & -0.28 & & $\mathrm{Hu}(2012)$ \\
\hline
\end{tabular}

$* p<0.05, * * p<0.01, * * * p<0.001$

species and activated sludge process performance, even though for some species as V. microstoma or A. cicada some patterns were observed. Both ciliates $V$. microstoma and A. cicada tend to be generally negatively correlated with $\mathrm{BOD}_{5}$ and $\mathrm{COD}$ concentrations in the effluent (Table 4), whereas flagellates tend to be generally positively correlated with SVI, BOD, and SS concentration in effluent (Table 5).

Zornoza (2017) showed that there were significant differences between bioreactors in environmental variables and seasonality, so it was impossible to construct one model of environmental interpretation which would help to explain population dynamics of protozoans, metazoans, and filamentous bacteria community. From the ecological point of view changes in the microbial community should be interpreted together with environmental variables in each bioreactor separately to develop models with better possibilities of predicting system functions (Zornoza 2017). Until now only a few researchers (Curds 1965, 1973, 1982; Ettl 2001; Madoni 2011) investigated ciliated protozoa in WWTP trying to explain changes in a microbial community. Numerous studies, e.g., Al-Shahwani and Horan (1991), Chen et al. (2004), Zhou et al. (2008), Hu et al. (2013a), and dos Santos et al. (2014), were limited to presenting a ciliated protozoa community composition and potential bioindication value of species without ecological interpretation and references to fluctuations of a microbial community.

For the purposes of this work, multivariate analysis of some process parameters as, e.g., temperature, sludge load, and HRT explained less than $12 \%$ of the variance in protozoa and metazoa community composition. This led to the conclusion that additional parameters should be included in the future analysis 
of activated sludge biocenosis, although in our study, we used all data available from WWTP operators. We agree with Zornoza (2017) who postulated that during exploration of the relationship between protozoan, metazoans, and environmental variables also the typology of these variables should be taken into account. For WWTP plant operators it is crucial to know which factors affecting the microbial community are under their control and which are not. Much earlier Salvadó and co-workers (1995) drew attention to limitations of assessment of effluent quality based on ciliates occurrences and densities. The presence of a particular ciliate species in activated sludge depends on several factors such as the composition of the influent, operational parameters, and the relations with the other species of the community. Similarly, Curds (1982) claimed that simple correlations between daily changes in BOD and the protozoa species structure should not be expected, because the structure of the protozoan population in sampling time reflects changes in physical, chemical, and biological environmental conditions over the past few days. Moreover, Curds and Cockburn (1970) underlined that their "indicator method" should not be used to predict effluent BOD concentration but should be treated as a tool to assess the general information about the efficiency of activated sludge performance.

Control of effluent quality on the base of microbial community composition is especially useful in the case of unexpected and undetermined toxic influents. The standard procedure of influent examination does not cover a plethora of toxic substances hampering aquatic organisms. The drastic decline of metazoans and protists diversity is most often a clear signal of disturbances caused by toxins, among them heavy metals (Madoni et al. 1996; Papadimitriou et al. 2007). It is highly probable that difficulties in the determination of clear patterns in the relation between protists' composition and effluent quality are caused by such "noise" of toxic substances undetected by standard chemical analysis.

It is also worth to underline that in our research it was hard to discriminate bioindicators among protists as variance in performance of four examined WWTPs was very low. All investigated plants worked properly, without distinct perturbances, and with good effluent quality. All biological indicator systems should be regarded with caution since they oversimplify extremely complex ecological interactions (Curds and Cockburn 1970). However, we still do not have a cheaper and faster method of assessment of the potential environmental risk of WWTP effluent for rivers and lakes than microscopic evaluation of biodiversity of protozoa and metazoa inhabiting activated sludge.

\section{Conclusions}

- The density and species composition of protozoa and metazoa in activated sludge depend mainly on bioreactor configuration (volume, technology used).
- For investigated treatment plants dominating species of protozoa and metazoa were defined.

- The joint effect of temperature, sludge load, and HRT on protozoa and metazoa community was significant.

- The effect of temperature on protozoa and metazoa community was the strongest but only slightly explained the variance in community composition.

- Changes in SVI had a significant effect on protozoa and metazoan community but explained only $5.55 \%$ of the variance in community composition.

Acknowledgments We would like to thank Anna Kubicka, Katarzyna Pawlik, Marcin Politowicz, and Edward Szmyd for the help with sample preparation.

Funding This research was funded by The National Centre for Research and Development and The National Fund for Environmental Protection and Water Management Grant (GEKON1/O3/214361/8/2014) and Jagiellonian University Funds (DS/WBiNoŚ/INoŚ/758).

Open Access This article is licensed under a Creative Commons Attribution 4.0 International License, which permits use, sharing, adaptation, distribution and reproduction in any medium or format, as long as you give appropriate credit to the original author(s) and the source, provide a link to the Creative Commons licence, and indicate if changes were made. The images or other third party material in this article are included in the article's Creative Commons licence, unless indicated otherwise in a credit line to the material. If material is not included in the article's Creative Commons licence and your intended use is not permitted by statutory regulation or exceeds the permitted use, you will need to obtain permission directly from the copyright holder. To view a copy of this licence, visit http://creativecommons.org/licenses/by/4.0/.

\section{References}

Al-Shahwani SM, Horan NJ (1991) The use of protozoa to indicate changes in the performance of activated sludge plants. Water Res 25:633-638

Chen S, Xu M, Cao H, Zhu J, Zhou K, Xu J, Yang X, Gan Y, Liu W, Zhai J, Shao Y (2004) The activated sludge fauna and performance of five sewage treatment plants in Beijing, China. Eur J Protistol 40:147-152

Curds CR (1965) An ecological study of the ciliated protozoa in activated sludge. Oikos 15:282-289

Curds CR (1973) A theoretical study of factors influencing the microbial population dynamics of the activated-sludge process - I. The effects of diurnal variations of sewage and carnivorous ciliated protozoa. Water Res 7:1269-1284

Curds CR (1982) The ecology and role of protozoa in aerobic sewage treatment processes. Annu Rev Microbiol 36:27-46

Curds CR, Cockburn A (1970) Protozoa in biological sewage-treatment processes-II. Protozoa as indicators in the activated-sludge process. Water Res 4:237-249

dos Santos LA, Ferreira V, Pereira MO, Nicolau A (2014) Relationship between protozoan and metazoan communities and operation and performance parameters in a textile sewage activated sludge system. Eur J Protistol 50:319-328

Drzewicki A, Kulikowska D (2011) Limitation of sludge biotic index application for control of a wastewater treatment plant working with shock organic and ammonium loadings. Eur J Protistol 47:287-294 
Dubber D, Gray NF (2011) The influence of fundamental design parameters on ciliates community structure in Irish activated sludge systems. Eur J Protistol 47:274-286

Dymaczewski Z (ed) (2011) Poradnik eksploatatora oczyszczalni ścieków. PZITS, Poznań (in Polish)

Esteban G, Téllez C, Bautista LM (1991) Dynamics of ciliated protozoa communities in activated-sludge process. Water Res 25:967-972

Ettl M (2001) The ciliate community (Protozoa: Ciliophora) of a municipal activated sludge plant: Interactions between species and environmental factors. In: Foissner W (ed) Protozoological Monographs 1. Shaker Verlag, Aachen, pp 1-62

Fan XY, Gao JF, Pan KL, Li DC, Dai HH (2017) Temporal dynamics of bacterial communities and predicted nitrogen metabolism genes in a full-scale wastewater treatment plant. RSC Adv 7:56317-56327

Fiałkowska E, Pajdak-Stós A (2008) The role of Lecane rotifers in activated sludge bulking control. Water Res 42:2483-2490

Foissner W, Berger H (1996) A user-friendly guide to the ciliates (Protozoa, Ciliophora) commonly used by hydrobiologists as bioindicators in rivers, lakes, and waste waters, with notes on their ecology. Freshw Biol 35:375-482

Foissner W, Berger H, Kohmann F (1991) Taxonomische und Ökologische Revisionder Ciliatendes Saprobiensystems Band I: Cyrtophorida, Oligotrichida, Hypotrichia, Colpodea. Informationsberichte des Bayer. Landesamtes für Wasserwirtschaft, München (in German)

Foissner W, Berger H, Kohmann F (1992) Taxonomische und Ökologische Revisionder Ciliaten des Saprobiensystems Band II: Peritrichia, Heterotrichida, Odontostomatida. Informationsberichte des Bayer. Landesamtes für Wasserwirtschaft, München (in German)

Foissner W, Berger H, Kohmann F (1994) Taxonomische und Ökologische Revision der Ciliaten des Saprobiensystems Band III: Hymenostomata, Prostomatida, Nassulida. Informationsberichte des Bayer. Landesamtes für Wasserwirtschaft, München (in German)

Foissner W, Berger H, Blatterer H, Kohmann F (1995) Taxonomische und Ökologische Revision der Ciliaten des Saprobiensystems Band IV: Gymnostomatea, Loxodes, Suctoria. Informationsberichte des Bayer. Landesamtes für Wasserwirtschaft, München (in German)

Fredriksson NJ, Hermansson M, Wilén BM (2019) Long-term dynamics of the bacterial community in a Swedish full-scale wastewater treatment plant. Environ Technol 40:912-928

Hai R, Wang Y, Wang X, Li Y, Du Z (2014) Bacterial community dynamics and taxa-time relationships within two activated sludge bioreactors. PLoS One 9:e90175

Hu B, Qi R, An W, Yang M (2012) Responses of protists with different feeding habits to the changes of activated sludge conditions: a study based on biomass data. J Environ Sci 24:2127-2132

Hu B, Qi R, Yang M (2013a) Systematic analysis of microfauna indicator values for treatment performance in a full-scale municipal wastewater treatment plant. J Environ Sci 25:1379-1385

Hu B, Qi R, An W, Xu M, Zhang Y, Bai X, Yang M (2013b) Dynamics of the microfauna community in a full-scale municipal wastewater treatment plant experiencing sludge bulking. Eur J Protistol 49:491-499

Laybourn J, Finlay BJ (1976) Respiratory energy losses related to cell weight and temperature in ciliated protozoa. Oecologia 24:349-355

Lee S, Basu S, Tyler CW, Wei IW (2004) Ciliate populations as bioindicators at Deer Island treatment plant. Adv Environ Res 8:371-378

Liu J, Yang M, Qi R, An W, Zhou J (2008) Comparative study of protozoan communities in full-scale MWTPs in Beijing related to treatment processes. Water Res 42:1907-1918

Madoni P (1994) A sludge biotic index (SBI) for the evaluation of the biological performance of activated sludge plants based on the microfauna analysis. Water Res 28:67-75

Madoni P (2011) Protozoa in wastewater treatment processes: a minireview. Ital J Zool 78:3-11
Madoni P, Ghetti PF (1981) The structure of ciliated protozoa communities in biological sewage-treatment plants. Hydrobiologia 83:207-215

Madoni P, Davoli D, Gorbi G, Vescovi L (1996) Toxic effect of heavy metals on the activated sludge protozoan community. Water Res 30:135-141

Martin-Cereceda M, Serrano S, Guinea A (1996) A comparative study of ciliated protozoa communities in activated-sludge plants. FEMS Microbiol Ecol 21:267-276

Morishita I (1976) Protozoa in sewage and waste water treatment systems. Trans Am Microsc Soc 373-377

Ntougias S, Tanasidis S, Melidis P (2011) Microfaunal indicators, Ciliophora phylogeny and protozoan population shifts in an intermittently aerated and fed bioreactor. J Hazard Mater 186:1862-1869

Pajdak-Stós A, Fiałkowska E (2012) The influence of temperature on the effectiveness of filamentous bacteria removal from activated sludge by rotifers. Water Environ Res 84:619-625

Papadimitriou C, Palaska G, Lazaridou M, Samaras P, Sakellaropoulos GP (2007) The effects of toxic substances on the activated sludge microfauna. Desalination 211:177-191

Perez-Uz B, Arregui L, Calvo P, Salvadó H, Fernández N, Rodríguez E, Zornoza A, Serrano S (2010) Assessment of plausible bioindicators for plant performance in advanced wastewater treatment systems. Water Res 44:5059-5069

Salvadó H (1994) Effect of mean cellular retention time on ciliated protozoan populations in urban wastewater treatment plants based on a proposed model. Water Res 28:1315-1321

Salvadó H, Gracia MP (1993) Determination of organic loading rate of activated sludge plants based on protozoan analysis. Water Res 27: 891-895

Salvadó H, Gracia MP, Amigó JM (1995) Capability of ciliated protozoa as indicators of effluent quality in activated sludge plants. Water Res 29:1041-1050

Seviour RJ, Nielsen PH (2010) Microbial ecology of activated sludge. IWA Publishing, London

Ter Braak CJF, Smilauer P (2012) Canoco 5, Windows release (5.12). Software for multivariate data exploration, testing, and summarization. Biometris, Plant Research International, Wageningen

TIBCO Software Inc. (2017) Statistica (data analysis software system), version 13.3

Weisse T, Stadler P, Lindström ES, Kimmance SA, Montagnes DJ (2002) Interactive effect of temperature and food concentration on growth rate: a test case using the small freshwater ciliate Urotricha farcta. Limnol Oceanogr 47:1447-1455

Wu L, Ning D, Zhang B, Li Y, Zhang P, Shan X, Zhang Q, Brown MR, Li Z, Van Nostrand JD, Ling F, Xiao N, Zhang Y, Vierheilig J, Wells GF, Yang Y, Deng Y, Tu Q, Wang A, Global Water Microbiome Consortium, Zhang T, He Z, Keller J, Nielsen PH, PJJ A, Criddle CS, Wagner M, Tiedje JM, He Q, Curtis TP, Stahl DA, Alvarez-Cohen L, Rittmann B, Wen X, Zhou J (2019) Global diversity and biogeography of bacterial communities in wastewater treatment plants. Nat Microbial 4:1183-1195

Zhou K, Xu M, Dai J, Cao H (2006) The microfauna communities and operational monitoring of an activated sludge plant in China. Eur J Protistol 42:291-295

Zhou K, Xu M, Liu B, Cao H (2008) Characteristics of microfauna and their relationships with the performance of an activated sludge plant in China. J Environ Sci 20:482-486

Zornoza AMZ (2017) Estudio de la dinámica poblacional de protistas, metazoos y bacterias filamentosas y su interpretación ecológica en fangos activos. Doctoral dissertation, Universitat Politècnica de València. (in Spanish)

Publisher's note Springer Nature remains neutral with regard to jurisdictional claims in published maps and institutional affiliations. 